\title{
Participatory Roles of Private Sectors in Management of Home Economics Programme in Nigerian Higher Institutions
}

\author{
Nwokolo, C.K.C. \\ Azubuike, Ozioma C \\ Department of Home Economics \\ Federal College of Education(Technical) \\ Umunze-Anambra State \\ Nigeria
}

\section{Doi:10.5901/mjss.2013.v4n7p9}

\section{Abstract}

This paper focuses on roles of private sectors in management of Home Economics programme in Nigerian higher institutions of learning. The entire programme of Home Economics is not left for the government alone. The private sectors tries to allow the students of this area to carry out some exercise in their establishment like allow them to do the student SIWES, teaching practice etc.

\section{Introduction}

The story of Home economics is recognized at all levels of Education system in Nigeria from primary to tertiary. There is no doubt however that for Home Economics curriculum must be effectively implemented as to achieve the learning objectives. The programme must be carefully planned, organized and implemented which should include the participation of the private sectors in the management of Home economics.

\section{Higher Institution of Learning}

Tertiary education is the education given after the secondary education or its equivalent in the universities, the college of Education and Polytechnics including those institutions offering correspondence courses (FRN, 2004).

The goal of tertiary Education is to:

1. Contribute to the national development through a high level relevant manpower training.

2. Develop and inculcate proper values for the survival of the individual and the society.

3. Acquire both the physical and intellectual skills which will enable individuals to be self-reliant and useful members of the society.

Tertiary education plays a critical capacity building and professional training role in support of all the Millennium Development Goals (MDGs). Recent research findings indicate that expanding tertiary education may promote a country's ability and maximize its economic output (Bloom, et al., 2006) which Home Economics Programme is aimed at.

The Home Economics programme at the tertiary level is therefore designed to prepare professionally qualified individuals in Home Economics. The students should be knowledgeable in the principles of Home Economics and this should be able to demonstrate the skills and competences acquired while directly relating them to the job that is to be done. Specifically, the objectives at these levels are: 
1. To produce professionally qualified teachers who are competent to teach Home Economics at the post graduate levels.

2. To equip students with the intellectual and professional skills and other competencies required for self reliance.

3. To inculcate in the student the necessity to strengthen family life through improving personal, family life through community living.

4. To produce practical and production oriented graduate that will successfully utilize their skills to be self employed for services in private enterprises in addition to teaching jobs.

Proximate goals on the other hand, indicate likely sequence of development of behaviors on a varying period. The time is however less than that of the mediate goals. At level of proximate goals, the instructional materials and methods can easily be selected. A typical example is this: at a given level of a university Home Economics Education Programme, the ultimate goal of the students in a clothing and textile course is to acquire the right knowledge and skills in pattern drafting and construction, cutting, sewing of garment, etc. the mediate goals will be to make a complete dress with a full knowledge on pattern drafting through free hand cutting and the proximate goals will of course be for the students to be able to identify various sewing equipments, take measurements and draft pattern block on papers.

The ultimate goals are the expected outcome or products of an education carried out over a long time. They are the behavior that the students expected to have acquired from the education they have received. The ultimate goal for students at the tertiary level who have acquired learning in Home Economics is to acquire the right saleable skills needed in the major area likes food and nutritional, clothing and textile, Home management etc, and achievement of the learning objectives. The mediate goals are the patterns of expected behavior at given stages over the educational period. As patterns of behavior are developed through learning, it is expected that the behavior of a 15year old will be different from that of a 10year old student.

The component of a typical Home Economic Programme will include the following:

1. Vocational Home Economics

2. Co-operative Home Economics

3. School release time

This is a programme which prepares male and female recipients for gainful employment and home making.

It also involves those forms of education that includes training and retraining which is designed to prepare individuals to enter or continue in gainful employment or experience. Vocational Home Economics is an education that helps individuals to discover or rediscover, define or redefine their talents irrespective of sex.

In order to achieve this, the vocational Home Economics Programme(s) have been divided into two main programme:

1. Comsumer and home making education

2. Occupational Home Economics

This consists of instructional programmes, services and activities at all educational levels for occupation of home making such as consumer education, food and nutrition, family living, parenthood education, child development and guidance, housing and furnishing, house managements, clothing and textiles, etc.

i. To encourage participation of both males and females to be prepared for combining roles of home making and wage earning.

ii. To encourage the elimination of sex bias by promoting the development of human and material resources thus deals with:

a. Increased number of women working outside the home

b. Increased number of men assuming home making responsibilities 


\section{c. Changing career patterns of males and females.}

iii. To give greater consideration to economic, social and cultural conditions and needs.

iv. To encourage eligible recipients of the education to operate outreach programmes in communities for youth and adult, example extension workers. These people go to homes giving lectures about work simplification techniques, child care, house hold repairs, simple renovations and how to make proper use of little space they have, etc.

This consists of instructional programme, services and activities for preparation for employment in the labour force/ market, utilizing the knowledge and skills of home making education.

For optimum quality of life individuals and families this programme has been described as Home Economics Education for gainful employment as in the case of consumer and Home making education.

This concerns mainly educational programmes for students enrolled in schools. In this type of programmes there is a co-operative arrangement between the school and employers of various occupational establishments so that for a while, students will be sent out of school to practice their knowledge and skills. The school intermittently checks and supervises the students while they are at work in these various occupational establishments. An example is the Students Industrial Work Experience Scheme (SIWES) Industrial Training Programme.

Here, the students are released to attain occupational and experiences during a portion of the school's time probably to get some money. There is no arrangement between the school and the students.

Occupation al Home Economics curriculum is planned and developed on the basis of knowledge, skill and attitude for successful employment in a particular job or job clusters. The curriculum is designed so that students will have marketable skills even if they will learn the programme before the completion. A typical school release time programme is the period of work experience between the ordinary National Diploma (OND) and Higher National Diploma (HND) as in the case of polytechnics.

This programme is designed to be comprehensive, which include all or most of the Home Economics Programme. Traditionally, the Home Economics Programme is organized from the primary level of education to the tertiary level of education.

At the primary level, the programme is organized as domestic science, needle work, or as Home Economics. The pupils are exposed to various areas and level of the subject area according to the level of understanding of the pupils in question.

At the secondary school level in Nigeria, the programme is organized as a series of sequential courses that combine several areas of instruction. Thus each course is comprehensive in nature. In earlier years, a common pattern involved the organization of the programme according to three or four sequential courses although special interest courses were sometimes available in Junior and Senior Secondary schools. The whole programme as it stands now at the secondary school level in Nigeria is such that at the junior level, the subject is treated as a whole and comprehensive in nature too. The students are exposed to deal with all the aspects and areas of the subject without a choice of specialization. The case however is different at the senior level where the students are given a choice of option. The programme therefore is divided into three major and common areas namely:

Food and nutrition, clothing and textiles, and home management. Any school offering the programme at that level is thus expected to choose or take an option among the three categories depending on which it can adequately cope with. Some schools though still take two or more of the options available.

In recent years, there has been a trend towards reducing the number of comprehensive courses required and offering more courses in specialized comprehensive course.

\section{The Private Sectors and Its Participatory Roles in Home Economics Programme}

Private sectors are non-governmental organizations. They own their companies or firms to themselves. These sectors have great roles to play in Home Economics programme in the following ways: 
- Industrial Attachment (SIWES) Programmes. In these aspects, they try to allow the students or graduates of Home Economics to carry out some duties in their firm. Such firms like fast food joints, UAC companies, Textiles industries, etc where students learn some skills to add to the ones already learnt at school. In this case, they may or may not pay the students rather they help them to improve on their skills and knowledge.

- Another, the private sectors could employ a Home Economics graduate. That is giving them a paid job as a source of earning a living.

- Students that have Home Economics background needs an understanding of the broad areas of Home Economics. They need to see how Home Economics can help them to achieve greater personal satisfaction and a higher level of living. The following suggestion may stimulate you in thinking of ways in which Home Economics can promote better understanding of home life.

- Proprietors of schools should endevuor to employ the graduates of Home Economics to teach in their establishment and baby- sit kids in the crèche/ day care centers. Most often these private sectors do not employ such graduates because the establishment cannot pay them

\section{Conclusion}

Through NGOs, Nigeria can effectively take care of the back log from JAMB admission to Universities and also extend education to those who hitherto have been shut out from university education because of social, economic, religious or any other reasons. To successfully do this, the private sector must support the federal government through the establishment of more private universities that study Home Economics to boost the quality of Home Economics students in Nigeria.

\section{Recommendations}

The following recommendations were made:

1. The government should support thes private sectors to employ the Home Economics graduates and pay them well.

2. The private sector should motivate the home Economics graduates to encourage the study of the programme

\section{References}

Enemuoh, E. U. (2010): issues in organization and Evaluation of Home Economics. Nimol:Rex Charles \& Patrick Publications.

Federal Republic of Nigeria (2005) National Policy on Education Yaba, Lagos NERDC press.

Home Economics in institutions Granting Bachelor's or Higher Degrees, 1993 Washington, D.C American Home Economics Association.

Ojerinde, O. (2011): Using assessment for Improvement of tertiary education in Nigeria. Being a paper presented at the 35th International Association for Educational Assessment (IAEA) Conference, Bros bane, Austrialia from 13th to 18th September, 2009. 